Hydrol. Earth Syst. Sci., 16, 4191-4204, 2012

www.hydrol-earth-syst-sci.net/16/4191/2012/

doi:10.5194/hess-16-4191-2012

(c) Author(s) 2012. CC Attribution 3.0 License.

(c) (i)

\title{
Suspended sediment load in the tidal zone of an Indonesian river
}

\author{
F. A. Buschman ${ }^{1}$, A. J. F. Hoitink ${ }^{1,2}$, S. M. de Jong ${ }^{1}$, P. Hoekstra ${ }^{1}$, H. Hidayat ${ }^{2}$, and M. G. Sassi ${ }^{2}$ \\ ${ }^{1}$ Institute for Marine and Atmospheric research Utrecht (IMAU), Department of Physical Geography, Faculty of Geosciences, \\ Utrecht University, The Netherlands \\ ${ }^{2}$ Hydrology and Quantitative Water Management Group, Department of Environmental Sciences, \\ Wageningen University, The Netherlands
}

Correspondence to: F. A. Buschman (frans.buschman@gmail.com)

Received: 8 July 2011 - Published in Hydrol. Earth Syst. Sci. Discuss.: 20 July 2011

Revised: 16 July 2012 - Accepted: 11 October 2012 - Published: 13 November 2012

\begin{abstract}
Forest clearing for reasons of timber production, open pit mining and the establishment of oil palm plantations generally results in excessively high sediment loads in tropical rivers. The increasing sediment loads pose a threat to coastal marine ecosystems, such as coral reefs. This study presents observations of suspended sediment loads in the Berau River (Kalimantan, Indonesia), which debouches into a coastal ocean that is a preeminent center of coral diversity. The Berau River is relatively small and drains a mountainous, still relatively pristine basin that receives abundant rainfall. In the tidal zone of the Berau River, flow velocity was measured over a large part of the river width using a horizontal acoustic Doppler current profiler (HADCP). Surrogate measurements of suspended sediment concentration were taken with an optical backscatter sensor (OBS). Averaged over the 6.5 weeks covered by the benchmark survey period, the suspended sediment load was estimated at $2 \mathrm{Mtyr}^{-1}$. Based on rainfall-runoff modeling though, the river discharge peak during the survey was supposed to be moderate and the yearly averaged suspended sediment load is most likely somewhat higher than $2 \mathrm{Mt} \mathrm{yr}^{-1}$. The consequences of ongoing clearing of rainforest were explored using a plot-scale erosion model. When rainforest, which still covered $50-60 \%$ of the basin in 2007 , is converted to production land, soil loss is expected to increase with a factor between 10 and 100. If this soil loss is transported seaward as suspended sediment, the increase in suspended sediment load in the Berau River would impose a severe stress on this global hotspot of coral reef diversity.
\end{abstract}

\section{Introduction}

Indonesia is the country with the largest area of coral reefs, which hosts the global biodiversity center of several groups of marine organisms (Tomascik et al., 1997; Spalding et al., 2001). At the same time, sediment loads from Indonesian islands are disproportionally large. Although the Indonesian archipelago accounts for only about $2 \%$ of the land area draining into the global ocean, it is responsible for 13 to $18 \%$ of the global sediment transfer to the oceans (Milliman et al., 1999; Syvitski et al., 2005; Milliman and Farnsworth, 2011). The disproportionally high sediment load from the Indonesian islands is due to the high topographical relief, the small size of the drainage basins with easily eroding rocks and heavy rainfall that characterizes the tropics (Milliman et al., 1999). Additionally, sediment loads in Indonesia are increasing at a higher rate than in other tropical regions because of large-scale deforestation (Syvitski et al., 2005; Milliman and Farnsworth, 2011). The increasing sediment loads pose a serious threat to coastal coral reef ecology (Edinger et al., 1998; Spalding et al., 2001; Fabricius, 2005).

Edinger et al. (1998) found a 30-60\% reduction of coral species diversity at land-affected reefs over a period of $15 \mathrm{yr}$ in Indonesia. The observed reef degradation is partly due to the increased sediment loads. Turbidity reduces photosynthesis and reduces the maximal depth where corals can survive (Rogers, 1990; Fabricius, 2005). Both turbidity and sedimentation have negative effects on coral reproduction, growth and survival, which may result in decreasing species richness (Fabricius, 2005). The distribution of turbidity may result in a zonation of coral reefs (McLaughlin et al., 2003). The distribution of turbidity of an Indonesian embayment hosting 


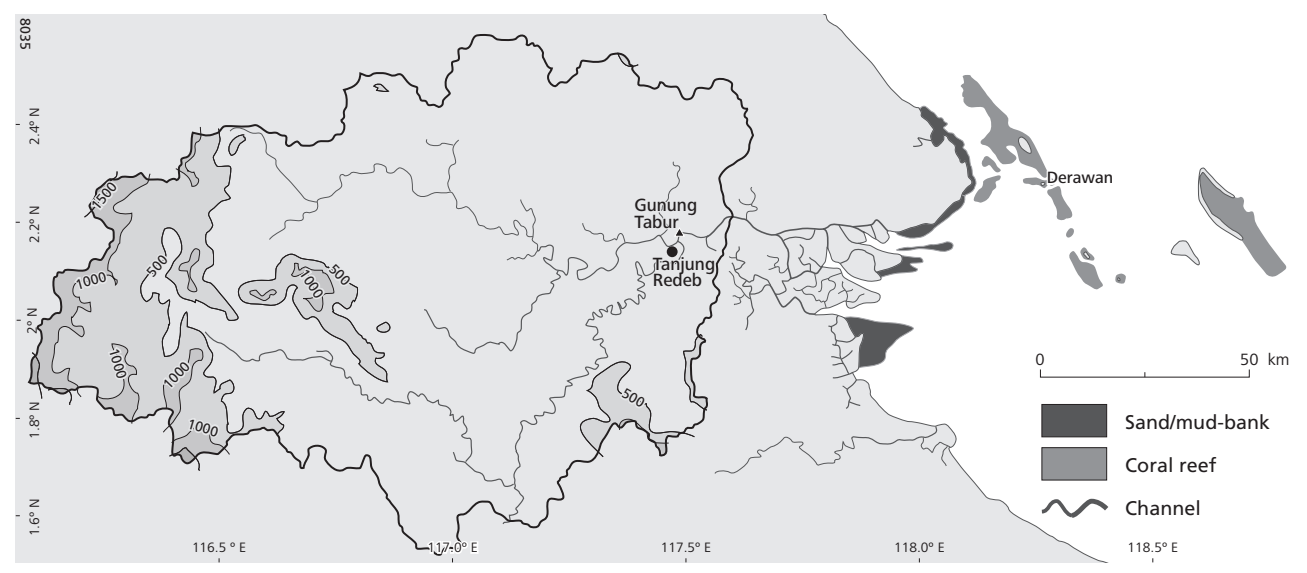

Fig. 1. Map of the Berau region showing the Berau drainage basin with contour heights $(\mathrm{m})$, the river and estuarine channels and the coral reef islands in the east.

coral reefs was studied by Hoitink and Hoekstra (2003) and Hoitink (2004), who found that turbidity levels bear a complex relation to the tidal motion and to flows driven by monsoons, and may peak above reef slopes as a result of cloud formation. In an embayment in Jamaica, Mallela et al. (2004) observed a clear increase of coral reef diversity with distance from the river mouth.

Despite the apparent impacts of sediment loads on coral reefs, there are few continuous records of suspended sediment loads in Indonesian rivers. This paper presents observations of flow and suspended sediment concentration in the Berau River, situated in Kalimantan, Indonesia (Fig. 1). The Berau drainage basin is relatively pristine. In 2007, rainforest still covered more than half of the drainage basin, although the rainforest cover is rapidly decreasing due to economic development (Ekadinata et al., 2010). The rainforest supports high densities of the Bornean orangutan (Marshall et al., 2007). The adjacent Berau continental shelf is host to an extremely diverse coral community (de Voogd et al., 2009) that shows a marked zonation with more turbid coastal reefs west of the Derawan reef chain, and oceanic reefs east of the chain (Fig. 1). This continental shelf is also of global interest due to the presence of several anchialine lakes and the presence of nesting grounds for the endangered green sea turtle (Tomascik et al., 1997; de Voogd et al., 2009).

The present contribution is part of the Berau research cluster, which is part of the bilateral Indonesian-Dutch East Kalimantan Programme (EKP) for coastal zone research. The potential of the Berau River as a source of pollution for the coastal ecosystems was investigated (de Voogd et al., 2009; van Katwijk et al., 2011). On the continental shelf, the tidal dynamics and the temporal and spatial behavior of the river plume were studied (e.g. Tarya et al., 2010). Suspended sediment may be transported to the reefs, whereas bed load may primarily be deposited near the channel mouths.

The main objective of this paper is to estimate the yearly averaged suspended sediment load in the Berau River. The Berau River is an example of an ungauged tropical river that drains a relatively pristine basin, but is facing rapid economic development. The suspended sediment load is estimated from continuous observations of flow and suspended sediment concentration, obtained in 2007 in the tidal zone of the Berau River. Observations of the suspended sediment load in the tidal zone of a river may provide better estimates of this load than observations taken further upstream. This study serves as a benchmark reference for suspended sediment loads to the Berau coastal shelf for the situation in 2007, when the catchment was relatively pristine, yet increasingly subject to anthropogenic disturbances.

The second objective of this paper is to estimate, at firstorder, how the suspended sediment load responds to projected land cover or land use (further termed "land cover" for brevity) changes. This response was high on the steep slopes of central Borneo, where Besler (1987) estimated that soil loss from hillslopes with bare soil was over 10000 times larger than losses from forested hillslopes. This study employs a simple erosion model to investigate the sensitivity of soil loss on land cover changes, which include forest clearing for timber production, open pit mining and conversion into oil palm plantations. Increasing soil loss implies elevated suspended sediment concentration in streams and rivers. In the Berau River, sufficient additional sediment transport capacity is available to convey additional sediment input from the catchment to the sea. Hence, additional soil loss could increase stress on the coral reefs and other marine ecosystems.

This paper continues with the field site, where details of the geology, climate and other characteristics of the Berau basin are provided. In the subsequent section the methods are described, including the calibrations necessary to obtain suspended sediment load and the erosion model. In the results section the time series of discharge and suspended sediment concentration are shown and outcomes of the erosion model are given. A discussion on the estimated yearly averaged suspended sediment load and its sensitivity to land cover is followed by the conclusions. 


\section{Field site}

\subsection{Geology and resources}

The Berau district, which encloses the Berau catchment, is situated on the Sunda plate. The Sunda plate is an extension of mainland southeast Asia that was uplifted and folded in the Tertiary (65-3 million years ago), associated with the northward movement of the Australian plate (MacKinnon et al., 1996). This tectonic movement created the topography of Borneo, including the high mountain range in central Borneo and the surrounding hilly landscape. Erosion of this mountain range over a period of about 15 million years has resulted in thick sedimentary deposits in basins, such as the Berau-Bulungan basin (Mantel, 2001). This basin contains pools of coal, gas and oil (Voss, 1982), which are important for the Berau district economically. Gold panning is of local economic importance in the district.

The dominant source rocks for soils in Borneo are sedimentary. Active volcanoes that are typical for most other Indonesian islands are absent in Kalimantan, the Indonesian part of the island Borneo. Sedimentary rocks are generally poor in weatherable minerals and rich in silica. When such sedimentary parent rocks are well drained, red-yellow podzolic soils develop, of which Ultisols are the dominant type (MacKinnon et al., 1996). Ultisols are usually very deep, less fertile and aluminium toxic soils, which both limits their use for crop production and makes them vulnerable to erosion (Mantel, 2001). Ultisols cover most of the Berau district. In the south of the district, a more fertile limestone area occurs (Voss, 1982). The karst formations, caves and limestone rainforests in this area are considered as one of the most valuable areas of Indonesia for conservation (MacKinnon et al., 1996).

The rainforest cover in the Berau district is rapidly decreasing (Table 1). Since the area of the Berau catchment is $55 \%$ of the entire Berau district area, Table 1 is representative for the Berau catchment. In the period between 2005 and 2008, which covers our fieldwork period, the total forest cover decreased by about $40 \%$. In 2007, when most of the observations for this study were made, the total forest cover in the Berau catchment was still about 50-60\%. This is high for Indonesia, since both legal and illegal logging of the rainforests occurs at large scale (Casson and Obidzinski, 2002). The logging yields timber, which is an important resource for the Berau district, and may be associated with establishing oil palm plantations. As a result of the logging, soil erosion rates increase dramatically (El-Hassanin et al., 1993; Moehansyah et al., 2004) and also sediment loads issued to the coastal sea may increase substantially.

\subsection{Climate}

The mean annual rainfall at Tanjung Redeb (Fig. 1) was $2105 \mathrm{~mm} \mathrm{yr}^{-1}$ over the observation period from 1987 to 2007 (Fig. 2). In this period, rainforest clearing has occurred,
Table 1. Forest cover $\left(\mathrm{km}^{2}\right)$ in time in the Berau district after Ekadinata et al. (2010).

\begin{tabular}{lrrrr}
\hline & 1995 & 2000 & 2005 & 2008 \\
\hline Undisturbed & 12196 & 8407 & 7551 & 4319 \\
Logged-over & 7121 & 7991 & 9497 & 5766 \\
Total & 19317 & 16398 & 17048 & 10085 \\
\hline
\end{tabular}

which may result in decreased rainfall (Bruijnzeel, 2004). Time series of rainfall did not show such a decreasing trend. During the El Niño period of 1997 and 1998 and the La Niña period of 1999, rainfall over Kalimantan was respectively lower and higher than average. These differences were not so pronounced at the meteorological station in the harbor town of Tanjung Redeb. Since the meteorological data were collected $20 \mathrm{~m}$ above mean sea level and rainfall is generally correlated with altitude, the station may underpredict the rainfall in the Berau catchment. Spatial patterns of rainfall presented by Voss (1982) show that rainfall was minimal at Tanjung Redeb and maximally 2.2 times higher at the highest altitudes. This spatial variability can explain the areal average rainfall estimated from the Tropical Rainfall Measuring Mission (TRMM, http://trmm.gsfc.nasa.gov/) averaged over the years 1998-2007, amounting to $2906 \mathrm{~mm} \mathrm{yr}^{-1}$.

The rainfall climatology from the Berau catchment (Fig. 2) shows characteristics of two out of three climatic regions in Indonesia as defined by Aldrian and Susanto (2003). The region that covers large parts of southern Indonesia experiences a strong influence of the wet northwest monsoon from November to March and of the dry southeast monsoon from May to September. In the second region, centered in western Indonesia, the monsoons are suppressed, resulting in small differences between the wet and dry seasons (Aldrian and $\mathrm{Su}-$ santo, 2003). In the Berau catchment the variation in monthly rainfall reflects both these climatic regions. The variation within a year is similar to within the first climatic region, whereas the difference between the wet and dry periods is limited as in the second.

\subsection{The Berau River}

Just upstream of the village of Gunung Tabur, two rivers join and form the Berau River (Fig. 1). The drainage basin of the Berau River is situated in between the larger drainage basins of the Kayan and the Mahakam rivers that also run in eastward direction. These two large rivers drain the highest mountains of central Kalimantan. The Berau catchment is about 14000 square kilometers, and the highest altitude is about $1800 \mathrm{~m}$.

The Berau River discharge at Gunung Tabur averaged $605 \mathrm{~m}^{3} \mathrm{~s}^{-1}$ during several months in 2007 (Buschman et al., 2009), which was an average year in terms of rainfall. At Gunung Tabur, the tidal regime is mixed, predominantly 


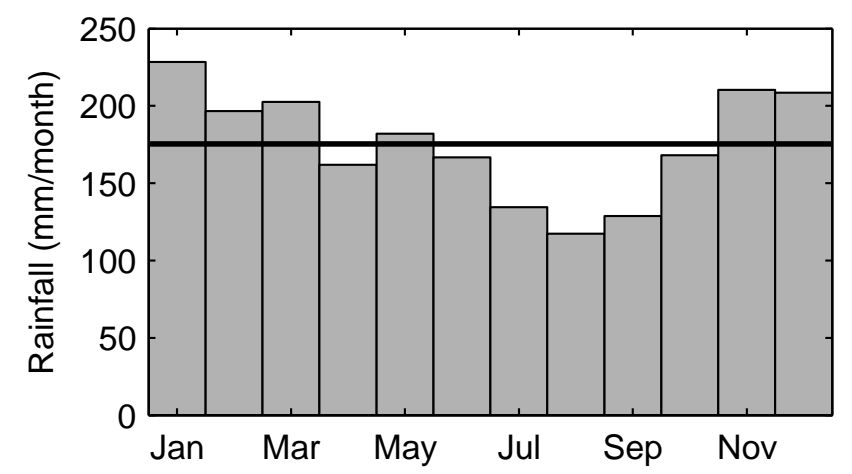

Fig. 2. Monthly rainfall at Tanjung Redeb based on the years 19872007. The annual average is $2105 \mathrm{~mm} \mathrm{yr}^{-1}$, which corresponds to an average monthly rainfall indicated by the thick line.

semidiurnal. The tidal range is about $1 \mathrm{~m}$ during neap tide and $2.5 \mathrm{~m}$ during spring tide, which is similar to the coastal conditions. The cross-sectional area of the Berau River increases more or less exponentially going seaward (Buschman et al., 2009), which is associated with the increasing tidal prism.

The bathymetry around Gunung Tabur, where instruments were mounted on an existing wooden jetty, shows several deep troughs in the outer bend of the tidal river. The maximum depth in the cross-section of the wooden jetty was $8 \mathrm{~m}$ (Fig. 3). The bathymetry was obtained by navigating transects across the channel at least every $500 \mathrm{~m}$ with an echosounder and a GPS, correcting for water level variation, and interpolating along the channel.

\section{Methods}

\subsection{Data set}

Suspended sediment load at Gunung Tabur was estimated using observations from three instruments. A horizontal acoustic Doppler current profiler (HADCP) and an optical monitoring station (OMS) were deployed on a jetty, yielding continuous point measurements of flow velocity and turbidity, respectively. During 13-h boat surveys across the tidal river at Gunung Tabur, turbidity profiles were observed with an optical backscatter sensor (OBS). This specific cross-section was selected for two reasons. Two rivers join just landward of the cross-section, such that all water and sediment are conveyed in a single channel. Secondly, a firm jetty existed to which the HADCP and OMS could be mounted. Figure 4 gives an overview of the observation periods for the three instruments. This figure shows that, for a period of 6.5 weeks starting at Julian day 502, suspended sediment load can be derived from the overlapping discharge and turbidity time series.

This paper presents the same discharge data as analyzed by Buschman et al. (2009), which has a time step of 1 min. Two three-day periods of HADCP data were added to the data

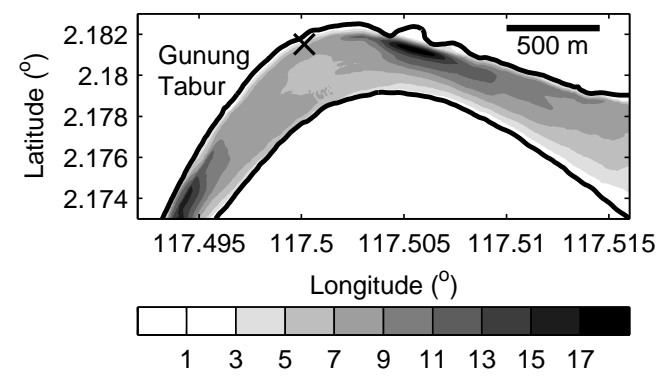

Fig. 3. Bathymetry of the Berau River close to the village Gunung Tabur showing depths with respect to mean water level (m). Instruments that obtain flow velocity and suspended sediment concentration were deployed at the location marked with an X.

series described in Buschman et al. (2009), during which the protocol was set up to collect the velocity profiles continuously at a high sampling rate of $2 \mathrm{~Hz}$ (last two periods in Fig. 4). The high-frequency data were collected to investigate processes of lateral momentum transfer in a future study, but serve here to complement the data series from Buschman et al. (2009), as they coincide with the OBS turbidity profiles.

\subsection{Obtaining continuous discharge}

As was done for Buschman et al. (2009), flow velocity data from the HADCP were converted to discharge $(Q)$ according to the methods described by Hoitink et al. (2009). The HADCP observed flow velocities at different HADCP cells across the tidal river. For each of these cells, the flow velocity was extrapolated to the bed and the water surface, using a bed roughness coefficient that determines the shape of the flow velocity profile and the relative depth of the cell. This flow velocity profile was integrated over depth, resulting in the specific discharge at a cell. For each cell the specific discharge was stochastically related with total discharge. Total discharge was observed during calibration periods by navigating transects across the tidal river with a vessel mounted downward-looking acoustic Doppler current profiler. The stochastic relations from the calibration were used to obtain total discharge from the specific discharge at each HADCP cell for the whole HADCP observation period. Finally, the independent estimates of total discharges resulting from each HADCP cell were averaged to yield the presented total discharge.

\subsection{Rainfall-runoff model}

A long-term (two years) river discharge series was generated by means of a rainfall-runoff model calibrated with the measured river discharge as described in the previous subsection. We used the lumped HBV light version (Seibert, 1997; Seibert and Beven, 2009) for discharge simulation of the Berau catchment upstream of Gunung Tabur. HBV is a simple conceptual model that is widely used and relatively easy to 


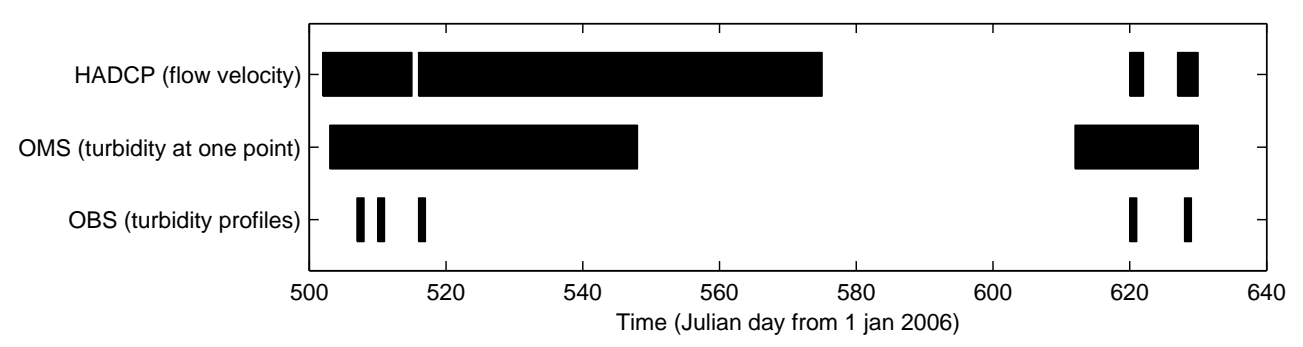

Fig. 4. Timeline per instrument of the measurements used in this study.

parameterize (Driessen et al., 2010). The model simulates daily discharge using daily rainfall, temperature and potential evaporation as input. Daily precipitation data were obtained from the TRMM at a spatial resolution of $0.25^{\circ}$ over the catchment. The areal average precipitation used to force the model was calculated as weighted mean of precipitation locations in and around the catchment. Potential evapotranspiration was estimated using the Penman-Monteith formula based on data from the meteorological station in Tanjung Redeb, and further refined by forcing the model to close the long-term water balance.

The model was calibrated using approximately four months of the available six months of measured river discharge. Calibration involved applying the Monte Carlo procedure by taking one million parameter sets. The sets were generated using random numbers within the given parameter ranges for the HBV soil and evaporation routine (three parameters), and groundwater and response routine (four parameters). Twenty parameter sets were selected to produce the daily discharge series. Each of these sets was associated with the best fit based on a fuzzy measure (Seibert, 1997) of three objective measures (i.e. Nash-Sutcliffe efficiency $R_{\text {eff }}$, $\log \left(R_{\text {eff }}\right)$, and mean difference). In addition, two more objective measures were added to the fuzzy measure. These objective functions were based on the $R_{\text {eff }}$ computed with 14 and 28 days averages of the time series. These averaging periods were used, since the tidally averaged discharge at the discharge station fluctuates with the spring-neap tide period (Buschman et al., 2009). These fortnightly fluctuations may lead to discrepancies with the simulated runoff. Table 2 shows the mean and standard deviation of the 20 parameter sets used in the calibrated HBV model. The daily discharge is obtained as the median of the 20 time series calculated with the best parameter sets and the calibrated HBV model.

\subsection{Obtaining profiles of suspended sediment concentration}

The vertical profiles of turbidity were measured with the OBS device every $50 \mathrm{~m}$ across the approximately 400-m-wide Berau River at Gunung Tabur. Profiles of turbidity were consequently measured covering tidal cycles at neap tide, at spring tide and during an intermediate tidal range in May (Julian day 510), and at neap and spring tide in September 2007 (Fig. 4). In September 2007 about 20 sets of profiles were taken across the river, attaining a higher temporal resolution than in May 2007.

Suspended sediment concentration $(c)$ was obtained from turbidity after calibration with in situ water samples. Simultaneously with the turbidity observations, 99 in situ water samples were collected. Half of the samples were taken at $1 \mathrm{~m}$ from the bottom and the other half at $1 \mathrm{~m}$ from the water surface. For each water sample a known volume of water was filtered through membrane filters with a pore size of about $0.45 \mu \mathrm{m}$. Drying the filter in an oven to remove water and organic matter from the residue, weighing the residue and dividing this weight by the filtered volume resulted in an estimate of $c$. Figure 5 shows the linear regression of $c$-estimates to optical backscatter in volts. Regarding this calibration, 7 of the 99 points were excluded based on a 4-sigma test. The resulting regression results in a high coefficient of determination ( $r^{2}$ in Fig. 5), suggesting that the sediment characteristics were not very different between May and September 2007. This high coefficient of determination is remarkable, since in other rivers usually the calibration parameters are not constant in time, and need to be determined for each individual survey. The obtained constant regression coefficients were used to obtain estimates of $c$ from the vertical profiles of turbidity.

For the two days in September 2007, which had a higher temporal resolution, the variation of $c$ within the crosssection was investigated. The concentration profiles were interpolated to a regular vertical interval of $0.1 \mathrm{~m}$. The top $0.3 \mathrm{~m}$ and the bottom $0.5 \mathrm{~m}$ were discarded, since these measurements could have been affected by air bubbles or by interference with the bed. For the spatial interpolation the vertical coordinate was expressed in terms of relative height, which is the height above the bed divided by the local total depth. All profiles were interpolated on a grid of relative height and distance from the right bank. Finally, a box filter was applied in time and over relative height to smooth the data. Figure 6 shows patterns of suspended sediment concentration at the cross-section under study for three stages during spring tide and neap tide. Those observations reveal that suspended sediment concentration features little systematic variation over width and depth. The variation in a vertical or horizontal profile is usually smaller than $10 \%$ and only occasionally reaches a maximum value of about $50 \%$. 
Table 2. Mean and standard deviation of the 20 parameter sets used in the calibrated HBV model, and the typical range of the parameters.

\begin{tabular}{llcccc}
\hline Parameter & Description & Range & $\begin{array}{c}\text { Unit of } \\
\text { measure }\end{array}$ & Mean & $\begin{array}{c}\text { Standard } \\
\text { deviation }\end{array}$ \\
\hline FC & Maximum water content in soil box & $50-500$ & $\mathrm{~mm}$ & 241.7 & 123.7 \\
LP & Threshold for reduction of evaporation & $0.3-1$ & - & 0.7 & 0.2 \\
BETA & Shape coefficient & $1-6$ & - & 3.5 & 1.5 \\
$K_{0}$ & Recession coefficient & $0.05-0.5$ & $\mathrm{~d}^{-1}$ & 0.25 & 0.11 \\
$K_{1}$ & Recession coefficient & $0.01-0.3$ & $\mathrm{~d}^{-1}$ & 0.16 & 0.08 \\
UZL & Threshold for peak flows & $0-100$ & $\mathrm{~mm}$ & 64.3 & 25.3 \\
MAXBAS & Length of weighting function & $1-6$ & $\mathrm{~d}$ & 3.2 & 1.3 \\
\hline
\end{tabular}

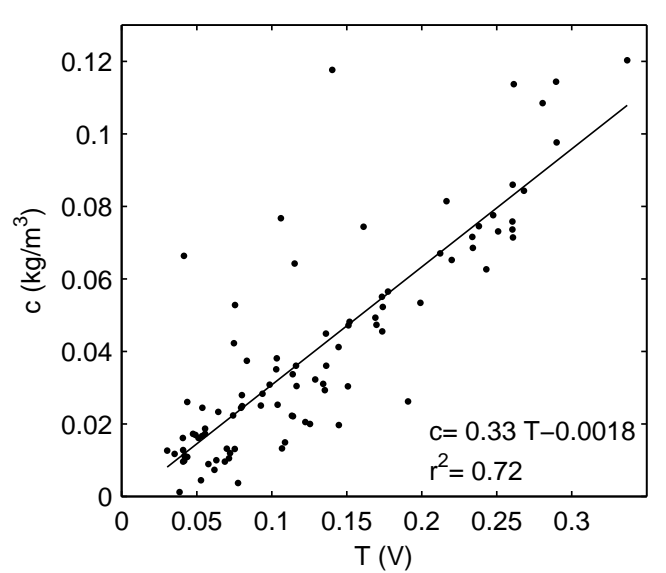

Fig. 5. Calibration of turbidity with total suspended matter $(c)$ from in situ water samples.

\subsection{Obtaining continuous suspended sediment concentration}

Turbidity was measured continuously with a 5 min interval using a 600 OMS manufactured by YSI, for several months. The OMS was deployed at the same jetty as the HADCP at about $1.5 \mathrm{~m}$ above the bed, which was between $25 \%$ and $50 \%$ of the local depth, depending on tidal stage. Although the optical backscatter sensor was equipped with a wiper and with a cage to protect the sensor, the turbidity signal often contained an increasing number of spurious peaks in each of the time series. The larger parts of those peaks were caused by biological fouling, with weeds, algae and shells growing on the instrument. Only two data series with relatively few spurious peaks were sufficiently reliable for analysis. The first time series lasted 6.5 weeks, and the second time series covered the two days when the high time resolution data were collected (Fig. 4).

For those two turbidity time series, data processing started by removing the spurious peaks. Turbidity samples exceeding 300 NTU, which were unlikely to be related to high turbidity of the water, were removed. Next, a moving window filter was applied, retaining the data points within 4 standard deviations from the median obtained over a $24 \mathrm{~h}$ period. A last filtering procedure was necessary only for a period between Julian days 538.5 and 542.5 , when some of the measured turbidities were high, whereas subsequent observations showed a low value. The highest signal was attributed to biological fouling and these points were removed. The number of points removed from the time series did not exceed $4 \%$ of the total, for each of the two series.

The valid points were interpolated and smoothed on a regular 5 min interval, using the methods of Schlax and Chelton (1992) with an overturning period of $3 \mathrm{~h}$. The resulting turbidity time series of September 2007 was linearly regressed against the cross-section averaged suspended sediment concentration $(C)$ derived from the OBS profiles. Although this turbidity index approach ignores variation of $c$ over the crosssection, Fig. 7 shows that the estimates of $C$ from the OMS turbidity correspond well to the corresponding OBS-derived values. Since the spatial variation of suspended sediment concentration is limited (Fig. 6), the point data from the OMS are largely representative for the cross-section. Also during the other three days with OBS cast observations, the spatial variation of suspended sediment concentration in the crosssection was limited (not shown), confirming that generally the point OMS data are largely representative for the crosssection. Finally, continuous suspended sediment load was estimated by multiplying discharge and the OMS derived suspended sediment concentration.

\subsection{Erosion model}

To investigate the sensitivity of suspended sediment load to land cover changes, we apply an erosion model. Since insufficient data were available to apply a distributed erosion model for the Berau drainage basin, we applied the Universal Soil Loss Equation (USLE) on a hillslope that is typical for the Berau drainage basin. Since the USLE is a widely used soil erosion model (Merritt et al., 2003; Jetten and Favis-Mortlock, 2006; Kinnell, 2010), missing parameter values can be estimated based on other studies. We did not use the revised USLE, since it involves additional variables that are unknown for this tropical drainage basin. Although the USLE describes plot-scale erosion processes, 

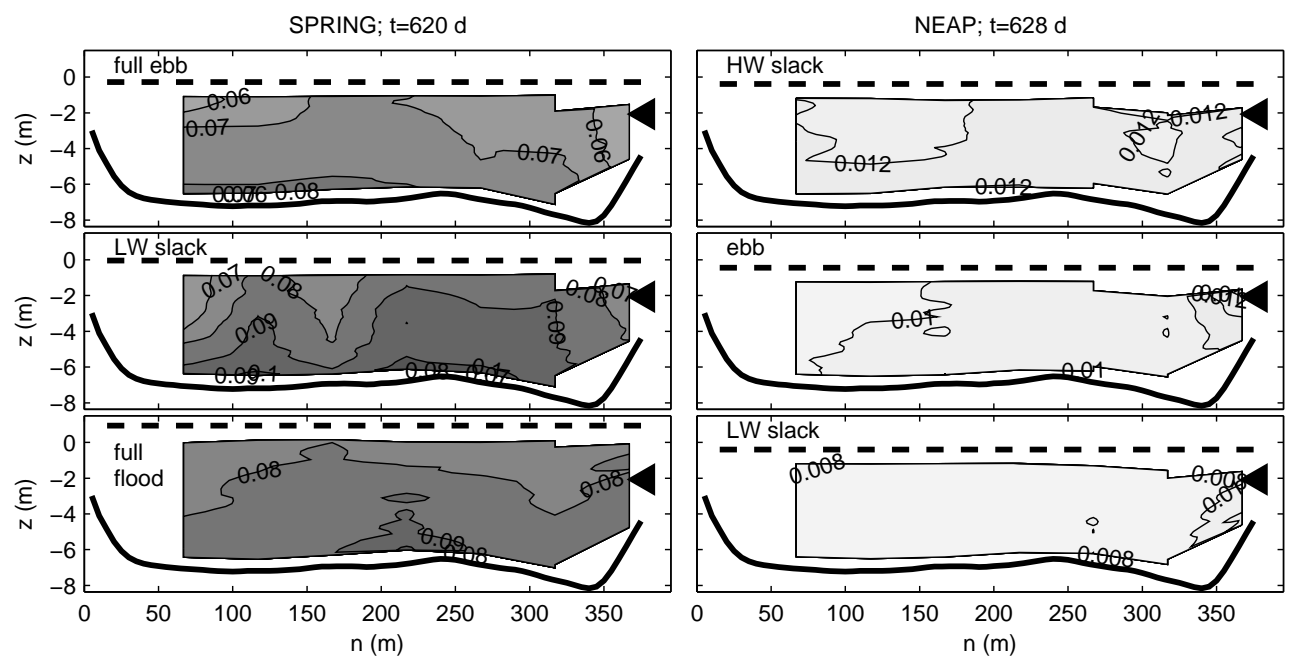

Fig. 6. Suspended sediment concentration from optical measurements $\left(\mathrm{kg} \mathrm{m}^{-3}\right)$ in the cross-section close to Gunung Tabur at three phases in a tidal cycle during spring tide (left) and during neap tide (right). The black triangle indicates the position of the HADCP.

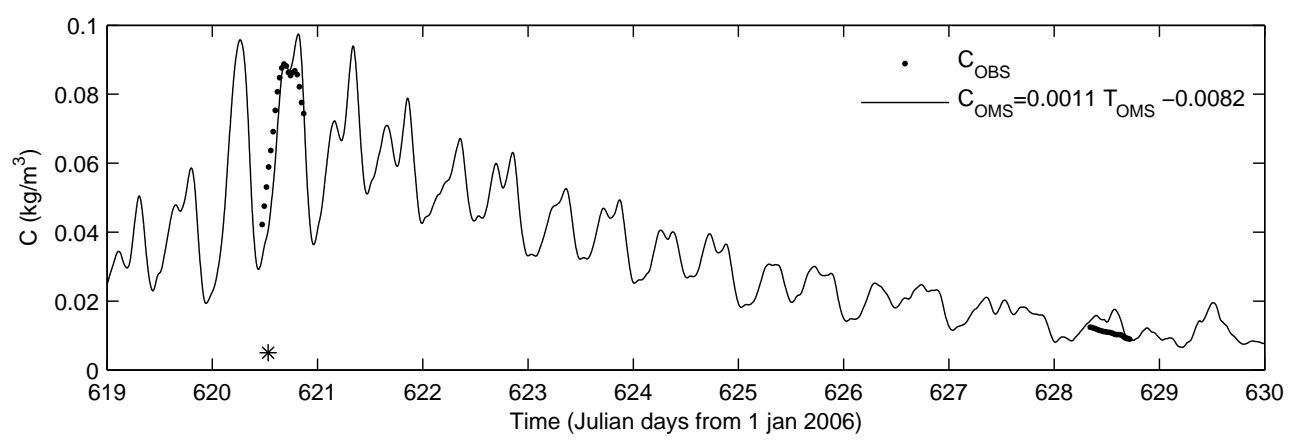

Fig. 7. Cross-section averaged suspended sediment concentration for 11 days in September 2007.

we assume that the model provides first-order estimates of the sensitivity of soil loss to land cover changes in the Berau catchment.

The USLE is an empirical erosion regression equation primarily based on observations. The annual soil loss per unit area $\left(A_{e}\right.$ in $\left.\mathrm{tha}^{-1} \mathrm{yr}^{-1}\right)$, averaged over a plot on a constant sloping hill, is calculated as follows (Wischmeier and Smith, 1978):

$A_{e}=R_{\mathrm{e}} K S_{\mathrm{s}} S_{1} C_{\mathrm{m}} P$

where $R_{\mathrm{e}}$ is the rainfall erosivity factor (MJ mm ha ${ }^{-1} \mathrm{yr}^{-1} \mathrm{~h}^{-1}$ ), $K$ is the soil erodibility factor (th $\mathrm{MJ}^{-1} \mathrm{~mm}^{-1}$ ), $S_{\mathrm{s}}$ is the slope-steepness factor $(-), S_{\mathrm{l}}$ is the slope-length factor $(-), C_{\mathrm{m}}$ is the cover and management factor $(-)$ and $P$ is the support practices factor $(-)$. Each factor in the USLE can be derived or estimated based on physical characteristics of a hillslope.

Table 3 gives an overview of the default input values for a hillslope that has characteristics typical for the Berau catchment. Because no high temporal resolution rainfall data were available for the Berau basin, $R_{\mathrm{e}}$ was estimated from annual precipitation ( $P$ in $\mathrm{mm} \mathrm{yr}^{-1}$ ) according to an empirical relation found for southeastern Australia (Yu and Rosewell, 1996):

$R_{\mathrm{e}}=0.0438 P^{1.61}$.

This relation is remarkably similar to the empirical relation that Renard and Freimund (1994) found for the United States, which suggests a universal nature of this relationship (Yu and Rosewell, 1996). Considering the small variation in the mean monthly rainfall at the meteorological station in Tanjung Redeb (Fig. 2), the default value of $R_{\mathrm{e}}$ was derived using the mean annual rainfall at that station. This value is lower than the representative value for the catchment, since annual rainfall at Tanjung Redeb is lower than at higher parts of the catchment.

For the soil erodibility factor $K$, the value for strongly weathered Ultisols was applied (Wischmeier and Smith, 1978), since they are the dominant soil type in the basin (Mantel, 2001). The factors $S_{\mathrm{s}}$ and $S_{\mathrm{l}}$ are usually derived jointly as 
Table 3. USLE factors for a hillslope that has characteristics typical for the Berau drainage basin, including $R_{\mathrm{e}}$ derived from rainfall during an average year and $C_{\mathrm{m}}$ that represents primary rainforest.

\begin{tabular}{lrl}
\hline USLE factor & Default value & Units \\
\hline$R_{\mathrm{e}}$ & 9820 & $\mathrm{MJ} \mathrm{mm} \mathrm{ha}^{-1} \mathrm{yr}^{-1} \mathrm{~h}^{-1}$ \\
$K$ & 0.013 & $\mathrm{th} \mathrm{MJ}^{-1} \mathrm{~mm}^{-1}$ \\
$S_{\mathrm{S}} S_{1}$ & 2.8 & \\
$C_{\mathrm{m}}$ & 0.006 & \\
$P$ & 1 & \\
\hline
\end{tabular}

$S_{\mathrm{s}} S_{1}=\left(\frac{L_{\mathrm{s}}}{22.1}\right)^{m}\left(65.41 \sin ^{2} \alpha+4.56 \sin \alpha+0.065\right)$,

where $L_{\mathrm{S}}$ is the length of the slope (m) and $m$ is an exponent between 0.2 and 0.5 depending on $\alpha$, which represents slope angle here (Wischmeier and Smith, 1978). Equation (3) is the result of a regression of data with slopes in between 2 and 10 degrees. Considering the rolling plains in the Berau drainage basin, a standard slope length of $22 \mathrm{~m}$ and a slope angle of 10 degrees were used.

The cover and management factor $C_{\mathrm{m}}$ is the ratio of the long-term soil loss from a vegetated area to the long-term soil loss from a bare fallow area. Values for land cover types that occur in the Berau catchment are presented in the results section together with the sensitivity of suspended sediment load to land cover change. The default value of 0.006 in Table 3 represents primary rainforest, which covers a large share of the drainage basin and especially the steeper parts where soil loss is large. Since no erosion protection measures were taken, the support practice factor was set to 1 .

\section{Results}

\subsection{Discharge}

The flow at Gunung Tabur is bidirectional. The daily peak discharge magnitudes differ little between flood tide and ebb tide (top panel of Fig. 8). Because ebb usually has a longer duration than flood tide, a net flow seawards occurs. The tidally averaged discharge $(\langle Q\rangle)$, obtained by applying a running mean over $24.8 \mathrm{~h}$ period to time series of discharge, is always positive. The maximum observed tidally averaged discharge was $1412 \mathrm{~m}^{3} \mathrm{~s}^{-1}$ and occurred at Julian day 545. During that event, the flow direction was seaward almost the entire day. The discharge peaked at $2896 \mathrm{~m}^{3} \mathrm{~s}^{-1}$, which corresponds to a cross-section averaged flow velocity of $1.0 \mathrm{~m} \mathrm{~s}^{-1}$.

The variation of $\langle Q\rangle$ is due to river discharge variations and tidal effects. Around spring tide bottom friction is elevated due to the relatively high flow velocity magnitudes, which results in a higher tidally averaged water level gradient than at neap tide (Buschman et al., 2009). Due to temporal water storage, the tidally averaged discharge is smaller during periods with increasing water level gradients. The variation of $\langle Q\rangle$ induced by the tides, however, is small with respect to the variation due to river discharge variation from runoff, which is partly caused by the small size of the river and the mountainous character of the catchment.

A two-year time series derived from the rainfall-runoff model (Fig. 9) is used to assess the representative character of the discharge (and suspended sediment load) data collected in the 6.5-week observation period. The calibration period for the discharge corresponds approximately to Julian days ranging from 530 to 630 ; the remainder of the observations are used for model validation. Discrepancies can be largely attributed to the forcing of the model, in particular, the precipitation time series. A sensitivity test was performed by calibrating and validating the model using two- and threeday averages of precipitation as model forcing. Averaging daily precipitation increased the overall agreement between modeled and observed discharge series in the validation period. Best agreement for the validation period $(r=0.86)$ was obtained by applying three-day averages of precipitation as model forcing. The two-year series of river discharge especially shows discrepancy with the observations in the highflows, highlighting the importance of extremes in long-term records (Fig. 9). Other discrepancies may be associated with the effect of tides, which is not captured by the model, and the inability of the present model to represent within catchment variations in vegetation and elevation zones.

The discharge averaged over the 6.5 weeks shown in Fig. 8 amounted to $703 \mathrm{~m}^{3} \mathrm{~s}^{-1}$, which is slightly higher than the river discharge averaged over the simulated two years $\left(667 \mathrm{~m}^{3} \mathrm{~s}^{-1}\right)$. In terms of drainage basin averaged rainfall, rainfall over the 6.5 -week period $\left(3268 \mathrm{~mm} \mathrm{yr}^{-1}\right.$ ) was also slightly higher than averaged over the years from 1998 to 2007 (2906 $\mathrm{mm} \mathrm{yr}^{-1}$ ). The highest observed river discharge peak was, however, lower than the various simulated peaks before and after this period (Fig. 9). Eight river discharge peaks in the two-year simulated period exceeded the highest observed tidally averaged discharge. The simulated river discharge exceeded $2100 \mathrm{~m}^{3} \mathrm{~s}^{-1}$ about one month before the 6.5 -week period, which is about $700 \mathrm{~m}^{3} \mathrm{~s}^{-1}$ higher than the highest observed tidally averaged discharge. Over the whole observation period of about 6 months, the $10 \%$ exceedance value based on the HADCP is nearly $800 \mathrm{~m}^{3} \mathrm{~s}^{-1}$, whereas it is around $1200 \mathrm{~m}^{3} \mathrm{~s}^{-1}$ for the two-year simulated discharge regime. Hence, the modeled time series suggests that the observed peak flow was still moderate and may be exceeded several times during a year.

\subsection{Suspended sediment concentration}

The middle panel of Fig. 8 shows the cross-section averaged suspended sediment concentration $(C)$, estimated from the OMS measurements. Values of $C$ vary considerably over a 


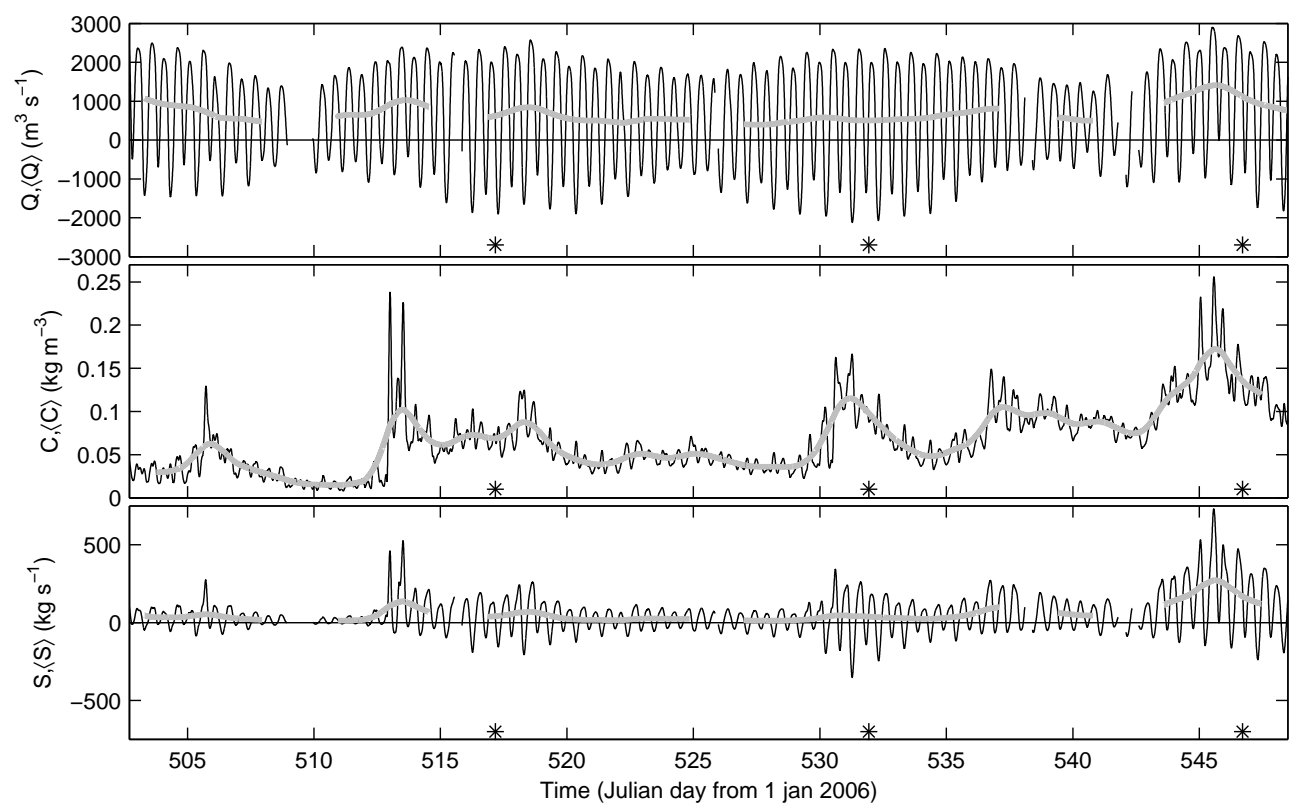

Fig. 8. Discharge (top panel), suspended sediment concentration averaged over the cross-section (middle panel) and suspended sediment load (bottom panel) during the 6.5-week period. The thick grey lines indicate the tidal average, and the stars indicate moments of spring tide.

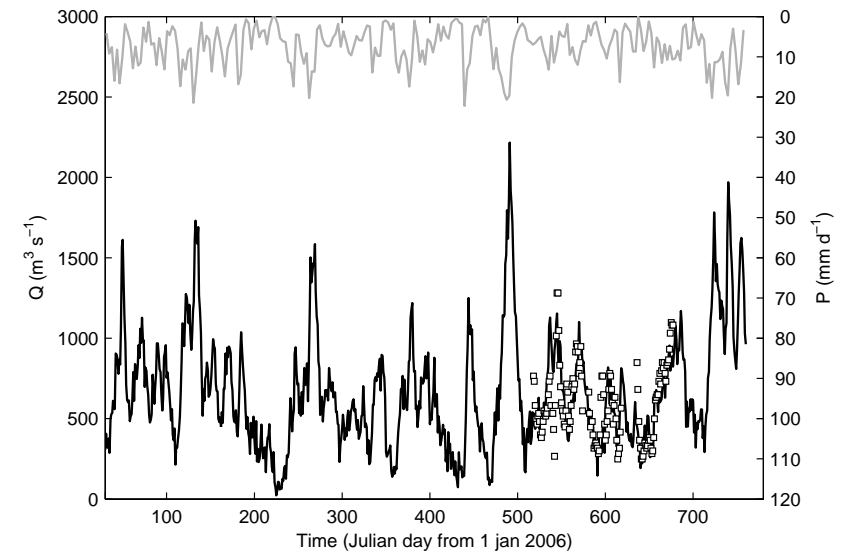

Fig. 9. Simulated river discharge (black line) and observed tidally averaged discharge (squares), along with the three-day average of the daily precipitation (upper grey line).

tidal period. The highest values occur most often in the ebb phase. The variation of $C$ within a day is generally highest around spring tide. The peak value of $C=0.26 \mathrm{~kg} \mathrm{~m}^{-3}$ coincides with the highest river discharge, at Julian day 545.

\subsection{Estimating suspended sediment particle size}

Both during spring tide and during neap tide, profiles of suspended sediment concentration $(c(n, z))$ generally showed a gradual increase towards the bed (Fig. 6). For those concentration profiles, observed during two days in September 2007, Rouse profiles were fitted, yielding a bulk estimate of the sediment fall velocity $\left(w_{\mathrm{s}}\right)$. Rouse profiles represent steady-state conditions when downward settling is balanced by upward diffusion of sediment. Under these conditions, $c$ at level $d+z$ above the bed $\left(c_{z}\right)$ relates to the reference concentration $\left(c_{\text {ref }}\right)$ at level $d+z_{\text {ref }}$ according to the following equation (Dyer, 1986):

$c_{z}=c_{\mathrm{ref}}\left(\frac{-z\left(d+z_{\mathrm{ref}}\right)}{(d+z)\left(-z_{\mathrm{ref}}\right)}\right)^{w_{\mathrm{s}} /\left(\beta \kappa u_{*}\right)}$.

The exponent governs the shape of the profile and is named the Rouse parameter. It consists of $w_{\mathrm{s}}$, shear velocity $u_{*}$, the Von Karman constant $\kappa$ that has a constant value of 0.4, and $\beta$, which is a constant of proportionality between the diffusion factors of suspended sediment and water, usually assumed to be unity (Dyer, 1986). Using $d+z_{\text {ref }}=z_{0}$ and inferring $u_{*}$ from the HADCP flow velocity data (Hoitink et al., 2009), $w_{\mathrm{s}}$ and $c_{\text {ref }}$ were derived from a best fit procedure.

The sediment particle diameter $\left(d_{\mathrm{s}}\right)$ can be estimated from $w_{\mathrm{s}}$ according to the Stokes' law (Dyer, 1986):

$d_{\mathrm{s}}=\left(\frac{18 \mu w_{\mathrm{s}}}{g\left(\rho_{\mathrm{s}}-\rho\right)}\right)^{0.5}$,

where $\mu$ is dynamic viscosity, $g$ is gravitational acceleration, $\rho_{\mathrm{S}}$ is density of the sediment particle and $\rho$ is water density. During spring tide $w_{\mathrm{s}}$ was estimated as $1 \times 10^{-3} \mathrm{~m} \mathrm{~s}^{-1}$, which corresponds to medium silt with $d_{\mathrm{s}}=29 \times 10^{-6} \mathrm{~m}$. During neap tide the variation in $c$ was smaller, resulting in a representative $d_{\mathrm{s}}$ that falls within the clay and fine silt fractions.

The estimated mean grain size was compared to the sediment size distribution of the bed. The sediment size distributions of 5 bed samples in the cross-section at Gunung Tabur were highly variable, showing peaks in the fine sand fraction. Minor peaks occurred at the clay and silt fractions, especially 
in samples taken near the banks. These minor peaks indicate that finer sediment particles are available for erosion from the riverbed. After erosion, these finer sediment particles remain suspended in the water column longer than coarser particles, which can explain the bulk sediment size as derived. Both the mean grain size of spring tide and neap tide may be considered relatively fine, explaining the small variation of $c$ over depth (Fig. 6).

\subsection{Suspended sediment load}

From $Q$ and $C$, a first-order estimate of the suspended sediment load $(S)$ can be obtained from

$S \approx Q C$.

Given the small variation of $c$ over the cross-section (Fig. 6), second-order effects are expected to be small. A small bias can be expected from the fact that flow velocity $(u)$ is highest near the surface, where $c$ is lowest, and vice versa near the bed. At the tidal cycle during spring tide, variations of $c$ in the vertical are largest, which can be explained from coarser sediment to be brought in suspension at that time. Using logarithmic profiles of $u$ (Hoitink et al., 2009) and the observed profiles of $c$ during spring tide, $S$ was calculated by integrating $u c$ over depth and width. The obtained more accurate estimate of $S$ showed a maximum deviation of $25 \%$ from the corresponding estimate derived from Eq. (6), confirming second-order effects to be minor .

The tidally averaged and instantaneous peak value of $S$ amount to $270 \mathrm{~kg} \mathrm{~s}^{-1}$ and $730 \mathrm{~kg} \mathrm{~s}^{-1}$, respectively. These peak values occur during the highest river discharge. Values of $S$ averaged over the full time series amount to $60 \mathrm{~kg} \mathrm{~s}^{-1}$, or $2 \mathrm{Mt} \mathrm{yr}^{-1}$. Lane et al. (1997) and French et al. (2008) stress that it is difficult to obtain a reliable estimate of tidally averaged $S$ in a tidal river, since tidally averaged $S$ is often only a small fraction of the instantaneous peak values. In the Berau River, tidally averaged values of $S$ exceed $20 \%$ of the instantaneous peak value of $S$, which places this general view in perspective. The underlying reason is that the tidal curves are not a superposition of a simple harmonic and a constant, representing discharge, which would result in peak ebb currents being much larger than peak flood currents. Instead, the duration of the ebb phase is longer to accommodate the river discharge, while peak ebb currents and peak flood currents are similar.

\subsection{Variation of tidally averaged $S$}

Tidally averaged $S$ was always directed seawards during the 6.5-week observation period (bottom panel Fig. 8). The variation in tidally averaged $S(\langle S\rangle)$ may be due to variations of $\langle Q\rangle$ and $\langle C\rangle$ or due to variations of $C$ and $Q$ within a tidal cycle (Meybeck et al., 2003):

$\langle S\rangle=\langle Q\rangle\langle C\rangle+\left\langle Q^{\prime} C^{\prime}\right\rangle$,

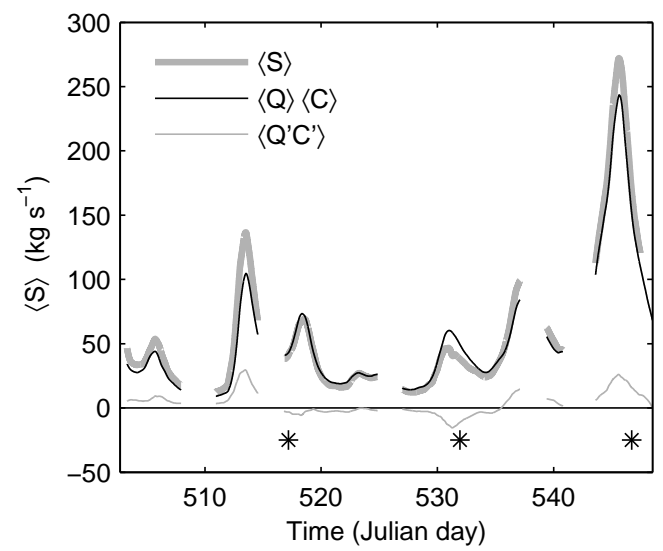

Fig. 10. Decomposition of suspended sediment load into tidal mean and intra-daily contributions, showing the latter to be small.

where the quotes indicate the deviation from the tidal average: $Q^{\prime}=Q-\langle Q\rangle$ and $C^{\prime}=C-\langle C\rangle$.

Figure 10 shows that the product $\langle Q\rangle\langle C\rangle$ dominates the dynamics. Tidally averaged discharge and suspended sediment concentration $(\langle Q\rangle$ and $\langle C\rangle$, respectively) are linearly correlated, yielding a coefficient of determination of $r^{2}=$ 0.5 . The product of the two, the tidally averaged suspended sediment load, thus increases non-linearly with river discharge. Due to this non-linearity, the period of high $\langle S\rangle$ is limited, exceeding $150 \mathrm{~kg} \mathrm{~m}^{-3}$ for only $8 \%$ of the time. Half of the suspended sediment load is concentrated only $25 \%$ of the time.

The contribution of intra-daily variations of $Q$ and $C$ only has a small contribution to $\langle S\rangle$, which is highest when variations in $C$ within a day are pronounced (Figs. 8 and 10). Since $C$ is usually elevated more during the peak ebb flows and the ebb duration is longer than flood duration, the correlation term $\left\langle Q^{\prime} C^{\prime}\right\rangle$ is usually directed seaward.

\subsection{Highest observed tidally averaged $S$}

To analyze the periods with the highest suspended sediment load, Fig. 11 zooms in on two peak events. The right panels show results from the period with the highest tidally averaged $S$, occurring at the highest river discharge. The peak flow velocities during ebb are higher than during lower river discharge, implying that also coarser bed particles may be resuspended. As a result, tidally averaged $C$ is also elevated. This elevation, in combination with the high ebb flow velocities and the long ebb periods, results in the highest observed $\langle S\rangle$ of $272 \mathrm{~kg} \mathrm{~s}^{-1}$.

The left panels indicate a period around Julian day 513, when the largest variation in $C$ was observed. At this day the flow velocity amplitude increases, with spring tide occurring three days later. Concurrently, the river discharge increases. During the two ebb periods of this day, $C$ shows peaks that are more than two times higher than the tidally averaged $C$. 


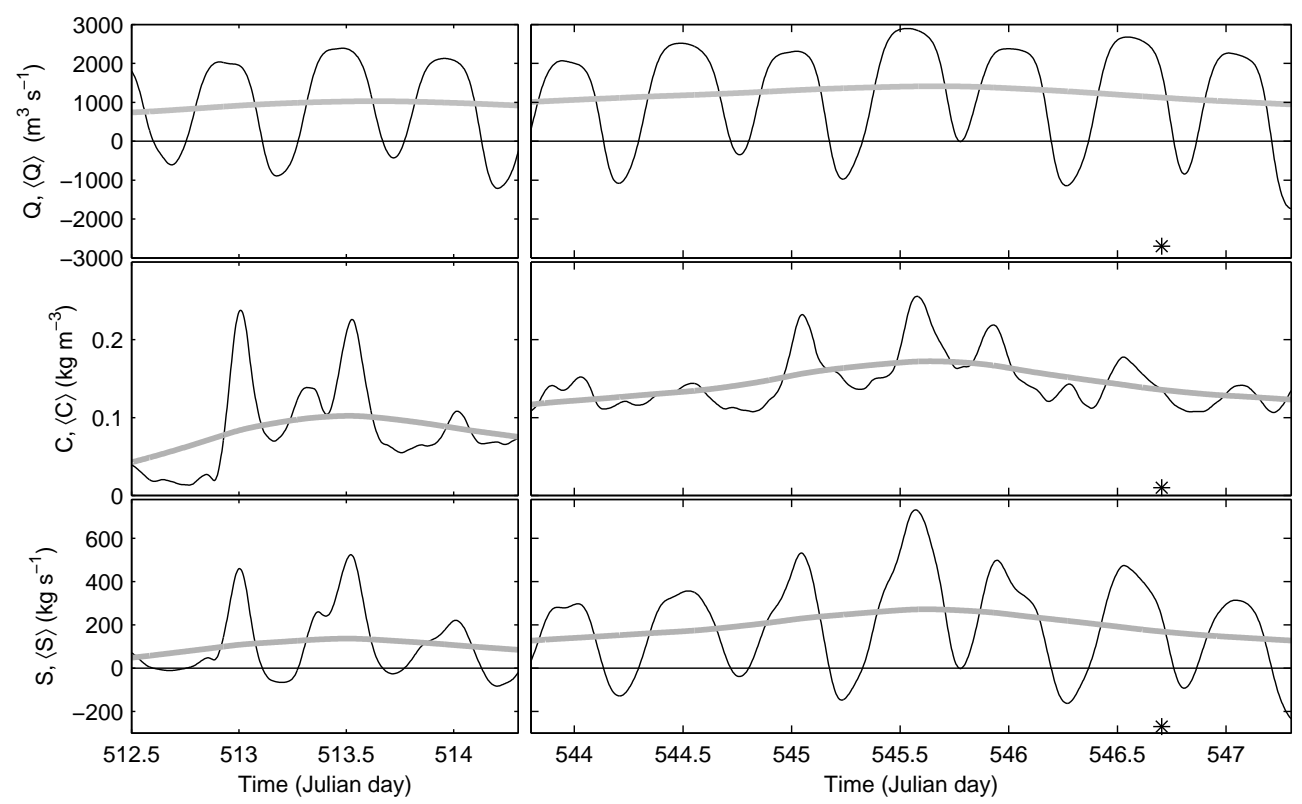

Fig. 11. As Fig. 8, now zoomed in on two periods with the highest observed tidally averaged suspended sediment load.

These dramatic increases of $C$ are likely related to high sediment discharge events in one of the two rivers that drain into the Berau River. Clouds of sediment may be passing by at Gunung Tabur in the Berau River, remaining unaffected by flow velocity variation.

\subsection{Erosion model}

The sensitivity of $A_{e}$ to land cover type appears to be high (Table 4). Annual soil loss from an oil palm plantation is about 50 times higher than from a primary rainforest subject to the same conditions. Soil loss from oil palm plantations is even higher than from areas subject to so-called shifting cultivation, which is practiced by the indigenous Dayak population. The soil loss that occurs from bare grounds, which represent the areas with open pit mining, is nearly 200 times higher than from primary rainforest. Considering that the rainforest cover was about $50-60 \%$ in 2007, conversion of this rainforest into intensive production land (Table 4) may result in 10-100 times higher soil loss in the drainage basin. If this additional sediment is transported to the rivers, suspended sediment loads in the Berau River may also increase with a factor 10-100 with respect to the situation in 2007.

\section{Discussion}

The observed suspended sediment load was $2 \mathrm{Mt} \mathrm{yr}^{-1}$ averaged over a 6.5 -week period with both valid flow and suspended sediment concentration observations. Averaged over this period, the drainage basin averaged rainfall and the river discharge were $11 \%$ and $5 \%$ higher than the yearly average, respectively. Although the average hydrologic conditions
Table 4. Cover and management factor and resulting annual soil loss per unit area for various tropical land cover types (Morgan and Finney, 1982; Besler, 1987; Morgan, 2005).

\begin{tabular}{lll}
\hline Land cover type & $C_{\mathrm{m}}(-)$ & $A_{e}\left(\mathrm{t} \mathrm{ha}^{-1} \mathrm{yr}^{-1}\right)$ \\
\hline Primary rainforest & 0.006 & 2 \\
Secondary rainforest & 0.002 & 0.7 \\
Traditional shifting cultivation & 0.001 & 0.4 \\
Coffee & $0.1-0.3$ & $36-108$ \\
Cacao & $0.1-0.3$ & $36-108$ \\
Rubber & 0.2 & 72 \\
Oil palm (with cover crops) & $0.3(0.1)$ & $108(36)$ \\
Groundnut & $0.2-0.8$ & $72-288$ \\
Bare ground & 1 & 360 \\
\hline
\end{tabular}

were similar to the yearly average, the observed suspended sediment load does not necessarily correspond with the yearly average. Averaged over the tides, the suspended sediment load was highest during the observed peak river discharge. In comparison with the simulated river discharge peaks based on rainfall records, the observed peak discharge was only moderate. The large simulated river discharge peak about one month prior to the observations may have transported large amounts of temporarily stored sediment seawards, reducing the availability of sediment in the system for subsequent floods. In catchments in Malaysian Borneo smaller than the Berau catchment, Douglas et al. (1999b) found that the bulk of suspended sediment load occurred only 5 days of the year. Since tidally averaged suspended sediment load generally increases non-linearly with river discharge and since an extreme river discharge peak was 
absent within the observation period, the yearly average suspended sediment load from the Berau River is most likely higher than $2 \mathrm{Mt} \mathrm{yr}^{-1}$.

The calculated suspended sediment load in the Berau River can be compared with estimates for other tropical rivers. The sediment yield from the Berau catchment averaged over the 6.5 -week period is $140 \mathrm{t} \mathrm{km}^{-2} \mathrm{yr}^{-1}$, whereas the annual average may still be somewhat higher. The closest river with a sediment yield estimate is the Mahakam River, which also drains to the east coast of Borneo. The yield from this relatively large river is similar to the estimate for the Berau River, amounting to $180 \mathrm{t} \mathrm{km}^{-2} \mathrm{yr}^{-1}$ (Storms et al., 2005). In contrast, Milliman and Farnsworth (2011) estimated that suspended sediment yields in Indonesia, the Philippines and Taiwan are higher than $1000 \mathrm{t} \mathrm{km}^{-2} \mathrm{yr}^{-1}$. The low figures for sediment yield from the Mahakam and Berau catchment can be explained by the old and deeply weathered rocks in east Borneo, since the sediment yield from tectonically active parts of Indonesia with volcanoes is about an order of magnitude higher (Douglas, 1999a).

The sediment yield and the associated suspended sediment load appear to be sensitive to land cover. The plot-scale erosion model indicates that soil loss from production land is 10-100 times higher than from rainforest land. Rainforest cover protects the soil against erosion. In 2007 the Berau drainage basin still had a relatively high rainforest cover of 50-60\%, which can also partly explain the low observed sediment yield. Remarkably, the soil loss from the erosion model for a rainforest cover (Table 4) times the drainage basin area is similar to the observed sediment yield. However, the primary aim of applying the USLE was not to validate our suspended load estimates, but to illustrate the impact of land cover change on sediment yield in this tropical catchment.

Over the past decades, the sediment supply of the Berau River has probably increased, since rainforests were cleared and subjected to land cover types that offer less protection to soil loss. From a comparison of historical and actual bathymetric maps, the morphological changes in the Berau River appeared to be limited, which suggests that the Berau River acts as a conduit of suspended sediment rather than as a trap. The Berau River splits into an estuarine channel network (Fig. 1), where accumulation of suspended sediment may occur. A comparison of bathymetric maps revealed that the most northeastern channel of the network has silted up significantly over the past decades (Buschman et al., 2010), which suggests that increased sediment loads may deposit in the estuarine system, rather than being issued to the coastal system. The degree in which the estuarine channel network acts as a sediment trap may be key to the seaward shift of the zonation of coral reefs as observed in the Berau coastal ocean.

\section{Conclusions}

A benchmark study was performed aiming to estimate the yearly averaged suspended sediment load of the Berau River, which is an Indonesian tidal river draining a still relatively pristine river basin. The Berau River discharges to the Berau continental shelf, which is an ecological hotspot of global importance. The suspended sediment load was observed in the tidal zone of the river. The suspended sediment load averaged $2 \mathrm{Mt} \mathrm{yr}^{-1}$ during a 6.5 -week observation period in 2007. During this period, rainfall and river discharge were similar to the yearly average. The highest observed river discharge, however, is smaller than peak values obtained with rainfall-runoff modeling for 2006 and 2007. Since suspended sediment load increases non-linearly with river discharge, the yearly averaged suspended sediment load is likely to be somewhat higher than $2 \mathrm{Mt} \mathrm{yr}^{-1}$.

A plot-scale erosion model was used to explore the first-order response of soil erosion to expected land cover changes. During observations in 2007, the rainforest cover in the Berau basin was 50-60\%, which is high compared to the rest of Indonesia. When this rainforest is converted to production land, such as oil palm plantation, the sediment yield due to soil erosion and the associated sediment load may increase 10-100 times, which will have serious consequences for the marine ecology of the Berau continental shelf.

Acknowledgements. This study was supported by grant WT 77-203 of WOTRO Science for Global Development, a division of the Netherlands Organisation of Scientific Research (NWO). We acknowledge M. C. G. van Maarseveen (Utrecht University) for preparing and maintaining the instruments and his technical assistance. We thank A. Tarya (Utrecht University) and a number of students from Wageningen University and Utrecht University who assisted during the field campaigns. The theses by M. Leenheer and K. Wetser (Utrecht University) contributed to this paper. Jan Seibert (University of Zurich, Switzerland) is acknowledged for providing us with the HBV light software. We thank three reviewers and $M$. van der Vegt (Utrecht University) for their constructive comments on an earlier version of this paper.

Edited by: N. Basu

\section{References}

Aldrian, E. and Susanto, R. D.: Identification of three dominant rainfall regions within Indonesia and their relationship to sea surface temperature, Int. J. Climatol., 23, 1435-1452, doi:10.1002/joc.950, 2003.

Besler, H.: Slope properties, slope processes and soil erosion risk in the tropical rain forest of Kalimantan Timur (Indonesian Borneo), Earth Surf. Proc. Land., 12, 195-204, 1987.

Bruijnzeel, L. A.: Hydrological functions of tropical forests: not seeing the soil for the trees?, Global Workshop on Bringing the Landscape into Focus, Chiang Mai, THAILAND, 12-13 November 2001, Agr. Ecosyst. Environ., 104, 185-228, 2004. 
Buschman, F. A., Hoitink, A. J. F., van der Vegt, M., and Hoekstra, P.: Subtidal water level variation controlled by river flow and tides, Water Resour. Res., 45, W10420, doi:10.1029/2009WR008167, 2009.

Buschman, F. A., Hoitink, A. J. F., van der Vegt, M., and Hoekstra, P.: Subtidal flow division at a shallow tidal junction, Water Resour. Res., 46, W12515, doi:10.1029/2010WR009266, 2010.

Casson, A. and Obidzinski, K.: From new order to regional autonomy: shifting dynamics of "illegal" logging in Kalimantan, Indonesia, World Dev., 30, 2133-2151, 2002.

de Voogd, N. J., Becking, L. E., and Cleary, D. F. R.: Sponge community composition in the Derawan islands, NE Kalimantan, Indonesia, Mar. Ecol.-Prog. Ser., 396, 169-180, doi:10.3354/meps08349, 2009.

Douglas, I.: Hydrological investigations of forest disturbance and land cover impacts in South-East Asia: a review, Philos. T. R. Soc. Lon. B, 354, 1725-1738, 1999a.

Douglas, I., Bidin, K., Balamurungan, G., Chappell, N. A., Walsh, R. P. D., Greer, T., and Sinun, W.: The role of extreme events in the impacts of selective tropical forestry on erosion during harvesting and recovery phases at Danum valley, Sabah, Philos. T. R. Soc. Lon. B, 354, 1749-1761, 1999 b.

Driessen, T. L. A., Hurkmans, R. T. W. L., Terink, W., Hazenberg, P., Torfs, P. J. J. F., and Uijlenhoet, R.: The hydrological response of the Ourthe catchment to climate change as modelled by the HBV model, Hydrol. Earth Syst. Sci., 14, 651-665, doi:10.5194/hess-14-651-2010, 2010.

Dyer, K. R.: Coastal and estuarine sediment dynamics, Wiley, 1986.

Edinger, E. N., Jompa, J., Limmon, G. V., Widjatmoko, W., and Risk, M. J.: Reef degradation and coral biodiversity in indonesia: Effects of land-based pollution, destructive fishing practices and changes over time, Mar. Pollut. Bull., 36, 617-630, doi:10.1016/S0025-326X(98)00047-2, 1998.

Ekadinata, A., Rahmanulloh, A., Pambudhi, F., Ibrahim, I., van Noordwijk, M., Sofiyuddin, M., Sardjono, M. A., Subekti, R., Dewi, S., Budidarsono, S., and Said, Z.: Carbon Emissions from Land Use, Land Use Change and Forestry (LULUCF) in Berau District East Kalimantan, Indonesia, Tech. rep., ICRAF Southeast Asia, 2010.

El-Hassanin, A. S., Labib, T. M., and Gaber, E. I.: Effect of vegetation cover and land slope on runoff and soil losses from the watersheds of Burundi, Agr. Ecosyst. Environ., 43, 301-308, doi:10.1016/0167-8809(93)90093-5, 1993.

Fabricius, K. E.: Effects of terrestrial runoff on the ecology of corals and coral reefs: review and synthesis, Mar. Pollut. Bull., 50, 125146, doi:10.1016/j.marpolbul.2004.11.028, 2005.

French, J. R., Burningham, H., and Benson, T.: Tidal and Meteorological Forcing of Suspended Sediment Flux in a Muddy Mesotidal Estuary, Estuaries Coasts, 31, 843-859, doi:10.1007/s12237008-9072-5, 2008.

Hoitink, A. J. F.: Tidally-induced clouds of suspended sediment connected to shallow-water coral reefs, Mar. Geol., 208, 13-31, 2004.

Hoitink, A. J. F. and Hoekstra, P.: Hydrodynamic control of the supply of reworked terrigenous sediment to coral reefs in the bay of Banten (NW Java, Indonsesia), Estuar. Coast. Shelf S., 58, 743755, doi:10.1016/S0272-7714(03)00181-1, 2003.

Hoitink, A. J. F., Buschman, F. A., and Vermeulen, B.: Continuous measurements of discharge from a Horizontal
ADCP in a tidal river, Water Resour. Res., 45, W11406, doi:10.1029/2009WR007791, 2009.

Jetten, V. and Favis-Mortlock, D.: Soil erosion in Europe, Chapter 50, John Wiley and Sons, online first: doi:10.1002/0470859202.ch50, 2006.

Kinnell, P. I. A.: Event soil loss, runoff and the Universal Soil Loss Equation family of models: A review, J. Hydrol., 385, 384-397, doi:10.1016/j.jhydrol.2010.01.024, 2010.

Lane, A., Prandle, D., Harrison, A. J., Jones, P. D., and Harvis, C. J.: Measuring fluxes in tidal estuaries: sensitivity to instrumentation and associated data analyses, Estuar. Coast. Shelf S., 45, 433451, 1997.

MacKinnon, K., Hatta, G., Halim, H., and Mangalik, A.: The ecology of Kalimantan; Indonesian Borneo, The ecology of Indonesia series: Vol. III, Periplus editions, Singapore, 1996.

Mallela, J., Perry, C. T., and Haley, M. P.: Reef morphology and community structure along a fluvial gradient, Rio Bueno, Jamaica, Caribb. J. Sci., 40, 299-311, 2004.

Mantel, S.: Berau model forest area environmental datasets and maps: land systems inventory, consultants report, DHV, BFMP, 2001.

Marshall, A. J., Salas, L. A., Stephens, S., Nardiyono, Engstrom, L., Meijaard, E., and Stanley, S. A.: Use of limestone karst forests by Bornean orangutans (Pongo pygmaeus morio) in the Sangkulirang Peninsula, East Kalimantan, Indonesia, Am. J. Primatol., 69, 212-219, 2007.

McLaughlin, C. J., Smith, C. A., Buddemeier, R. W., Bartley, J. D., and Maxwell, B. A.: Rivers, runoff, and reefs, Global Planet. Change, 39, 191-199, 2003.

Merritt, W. S., Letcher, R. A., and Jakeman, A. J.: A review of erosion and sediment transport models, Environ. Modell. Softw., 18, 761-799, 2003.

Meybeck, M., Laroche, L., Dürr, H. H., and Syvitski, J. P. M.: Global variability of daily total suspended solids and their fluxes in rivers, Global Planet. Change, 39, 65-93, doi:10.1016/S09218181(03)00018-3, 2003.

Milliman, J. D. and Farnsworth, K. L.: River Discharge to the Coastal Ocean: A Global Synthesis, Cambridge university press, Cambridge, United Kingdom, 1st Edn., 2011.

Milliman, J. D., Farnsworth, K. L., and Albertin, C. S.: Flux and fate of fluvial sediments leaving large islands in the East Indies, J. Sea Res., 41, 97-107, 1999.

Moehansyah, H., Maheshwari, B. L., and Armstrong, J.: Field evaluation of selected soil erosion models for catchment management in Indonesia, Biosyst. Eng., 88, 491-506, doi:10.1016/j.biosystemseng.2004.04.013, 2004.

Morgan, R.: Soil erosion and conservation, Blackwell publishing, Oxford, England, 2005.

Morgan, R. P. C. and Finney, H. J.: Stability of agricultural ecosystems: validation of a simple model for soil erosion assessment, Tech. Rep. cp-92-76, International institute for applied system analysis, Austria, 1982.

Renard, K. G. and Freimund, J. R.: Using monthly precipitation data to estimate the R-factor in the revised USLE, J. Hydrol., 157, 287-306, 1994.

Rogers, C.: Responses of coral reefs and reef organisms to sedimentation, Mar. Ecol.-Prog. Ser., 62, 185-202, 1990.

Schlax, M. G. and Chelton, D. B.: Frequency domain diagnostics for linear smoothers, J. Am. Stat. Assoc., 87, 1070-1081, 1992. 
Seibert, J.: Estimation of parameter uncertainty in the HBV model, Nord. Hydrol., 28, 247-262, 1997.

Seibert, J. and Beven, K. J.: Gauging the ungauged basin: how many discharge measurements are needed?, Hydrol. Earth Syst. Sci., 13, 883-892, doi:10.5194/hess-13-883-2009, 2009.

Spalding, M. D., Ravilious, C., and Green, E. P.: World Atlas of Coral Reefs, University of California Press, Berkeley, USA, London, England, 2001.

Storms, J. E. A., Hoogendoorn, R. M., Dam, R. A. C., Hoitink, A. J. F., and Kroonenberg, S. B.: Late-Holocene evolution of the Mahakam delta, East Kalimantan, Indonesia, Sediment. Geol., 180, 149-166, 2005.

Syvitski, J. P. M., Vorosmarty, C. J., Kettner, A. J., and Green, P.: Impact of humans on the flux of terrestrial sediment to the global coastal ocean, Science, 308, 376-380, 2005.

Tarya, A., Hoitink, A. J. F., and van der Vegt, M.: Tidal and subtidal flow patterns on a tropical continental shelf semiinsulated by coral reefs, J. Geophys. Res., 115, C09029, doi:10.1029/2010JC006168, 2010.
Tomascik, T., Mah, A. J., Nontji, A., and Moosa, M. K.: The ecology of the Indonesian seas; Part One, The ecology of Indonesia series: Vol. VII, Periplus editions, Singapore, 1997.

van Katwijk, M. M., van der Welle, M. E. W., Lucassen, E. C. H. E. T., Vonk, J. A., Christianen, M. J. A., Kiswara, W., Inayat al Hakim, I., Arifin, A., Bouma, T. J., Roelofs, J. G. M., and Lamers, L. P. M.: Early warning indicators for river nutrient and sediment loads in tropical seagrass beds: A benchmark from a near-pristine archipelago in Indonesia, Mar. Pollut. Bull., 62, 1512-1520, doi:10.1016/j.marpolbul.2011.04.007, 2011.

Voss, F.: Kalimantan Timur Atlas, East Kalimantan Transmigration Area Development (TAD), Hamburg: Institut für Wirtschaftsforschung, Hamburg, Germany, 1982.

Wischmeier, W. H. and Smith, D. D.: Predicting rainfall erosion losses- a guide to conservation planning, Agriculture Handbook No. 537, US department of Agriculture, Washington, 1978.

Yu, B. and Rosewell, C. J.: A robust estimator of the R-factor for the universal soil loss equation, T. ASAE, 39, 559-561, 1996. 